thời gian nằm và thời gian sử dụng kháng sinh của bệnh nhân Viêm phổi dao động từ 3 đến 19 ngày. Thời gian điều trị Viêm phổi tại bệnh viện của các bệnh nhi trung bình là $8,6 \pm 2,8$ ngày. Kết quả nghiên cứu tương đồng với nghiên của Nguyễn Thị Kim Loan thời gian trung bình của đợt điều trị là $7,48 \pm 0,62$ ngày [5].

\section{KẾT LUẦN}

Tỷ lệ tự ý sử dụng kháng sinh tại nhà khi trẻ bị viêm phổi còn cao (17,8\%). Sử dụng kháng sinh trong cộng đồng, trước khi nhập viện là một trong các nguyên nhân dẫn đến tình trạng lạm dụng thuốc và kháng thuốc kháng sinh trong điều tri.

Kết quả nuôi cấy cho thấy tỷ lệ gây bệnh chủ yếu nhóm vi khuẩn Gram (-) H.influenzae là $73,3 \%$, nhóm Vi khuẩn Gram $(+)$ là S.pneumoniae là $26,7 \%$.

H.Influenzae đề kháng cao với nhóm Ampicillin, Ampicillin-Sulbactam, Amoxicilin-Acid Clavulanic lần lượt là 98,5\%,95,5\%, 78,8\%. Tỷ lệ đề kháng với Cefuroxime, Cefotaxime, Ceftazidime, Ceftriaxone lần lượt là 97\%, 33,3\%, $22,7 \%, 21,2 \%$. Azithromycin tỳ lệ là $75,8 \%$. Đã ghi nhận đề kháng Imipenem với tỷ lệ 3\%.

S.Pneumoniae có tỷ lệ đề kháng cao $100 \%$ với Azithromycin, Erythromycin, Clarithromycin.
Tiếp đến là Tetracyclin với 79,2\%. Tỷ lệ đề kháng với Cefotaxime, Ceftriaxone, Chloramphenicol lần lượt là 45,8\%, 41,7\%, 12,5\%.

\section{TÀI LIẸU THAM KHẢO}

1. Trân Thị Anh Thơ (2014), "Đánh giá tình hình sử dụng kháng sinh trong điêuu trị Viêm phổi ở trẻ em từ 2 tháng đến 5 tuổi tại bệnh viện sản nhi Nghệ $A n^{\prime \prime}$.

2. Dương Thị Hồng Ngọc (2020), "Căn nguyền và mức đô để kháng khảng sinh của vi khuân gây Viêm phổi ở trẻ em từ 2 tháng đến dưới 5 tuổi", Tap chí y hoc dự phòng tháng 6/2020.

3. Nguyến Thị Ngọc Điệp (2016), "Đặc điểm lâm săng, cận lầm sàng của Viêm phổi do vi khuẩn và tính nhạy cảm với kháng sinh của một số loại vi khuẩn gầy Viêm phổi ở trẻ em từ 2 tháng đến 5 tuổi".

4. Pham Nhật Văn (2015), "Khảo sát tình hình kháng kháng sinh và xác định các typ huyết thanh bằng kỹ thuật sinh học phân tử của các chủng Streptococcus pneumoniae xâm lấn tại khu vực phía Nam Việt Nam", Tạp chí y học dự phòng tháng $1 / 2014$.

5. Nguyễn Thị Kim Loan (2017), "Nghiên cứu tình hinh sử dụng kháng sinh trong điêu trị Viêm phổi ở trẻ em tại Bệ̂nh viện trường Đai Học Y Dược Huế".

6. Phạm Anh Tuấn (2019), "Phân tích tình hình sử duñg kháng sinh điêu trị Viêm phổi mắc phải cộng đồng cho trẻ em tại Bệnh Viện Sản Nhi Quảng Ninh"'.

7. Nathan AM, Teh CSJ, Jabar KA, Teoh BT, Tangaperumal A, Westerhout C, et al (2020), "Bacterial pneumonia and its associated factors in children from a developing country".

\title{
TÌNH HÌNH NHIỄM VI KHUẨN GRAM ÂM Ở BÊNH NHÂN MỚI VÀO KHOA HỒI SỨC TÍCH CỰC BỆNH VIÊ̂N BACH MAI NĂM 2020-2021
}

\section{TÓM TẮT}

Nghiên cứu mô tả cắt ngang trên 168 bệnh nhân vào điều trị tại khoa Hồi sức tích cực - Bênh viện Bạch Mai trong vòng 48 giờ từ $01 / 8 / 2020$ đến $31 / 8 / 2021$ nhằm mô tả đặc điểm nhiễm vi khuẩn của bệnh nhân. Kết quả: Tỷ lệ nhiếm vi khuẩn gram âm đa kháng ở bệnh nhân mới vào khoa Hồi sức tích cực chiếm tỷ lệ cao trên $40 \%$; đặc biệt tỷ lệ vi khuẩn gram âm đả kháng cao hơn ở những bệnh nhân chuyển từ các khoa/trung tâm khác trong bênh viện chiếm $56,16 \%$ và tữ các bệnh viện khác chiếm $69,62 \%$ so với nhóm bệnh nhân từ cộng đồng chiếm 43,75\%; có sự khác biệt về tỷ lệ nhiễm vi khuẩn ở nhóm bệnh nhân từ

\footnotetext{
${ }^{1}$ Bệnh viện đa khoa Sóc Sơn

${ }^{2}$ Trường Đại học Y Hà Nội

Chịu trách nhiệm chính: Vũ Tuấn Dũng

Email: dr.vutuandung@gmail.com

Ngày nhận bài: 3.8.2021

Ngày phản biện khoa học: 30.9.2021

Ngày duyệt bài: 7.10.2021
}

Vũ Tuấn Dũng ${ }^{1}$ Đặng Quốc Tuấn ${ }^{2}$

cộng đồng và nhóm bệnh nhân chuyển từ bệnh viện khác $(p<0,05)$. 99,4\% số bệnh nhân có điểm SOF́A lớn hơn hoăc bằng 2. Kết luận: Những $B N$ đã có nhiễm khuẩn ở thời điểm vào khoa HSTC BVBM đều có tình trang năng. Đa số BN từ nơi khác chuyển đến có nhiễm vi khuẩn Gram âm đa kháng. Nhóm bệnh nhân nhiễm khuẩn cộng đồng cũng có hơn $40 \%$ niniềm VK Gram âm đa kháng.

Tì̛ khóa: Vi khuẩn gram âm, vi khuẩn gram âm đa kháng, khoa hồi sức tích cực

\section{SUMMARY \\ CURRENT STATUS OF GRAM NEGATIVE BACTERIAL INFECTION IN PATIENTS NEWLY ADMITTED TO THE INTENSIVE CARE UNIT OF BACH MAI HOSPITAL IN 2020-2021}

A cross-sectional descriptive study on 168 patients admitted to the ICU - Bach Mai Hospital within 48 hours from August 1, 2020 to August 31, 2021 to describe the patient's bacterial infection characteristics. Results: The rate of infection with multi-resistant gram-negative bacteria in patients 
newly admitted to the ICU accounted for a high rate of over $40 \%$; especially, the rate of multi-resistant gramnegative bacteria was higher in patients transferred from other departments/centers in the hospital, accounting for $56.16 \%$ and from other hospitals accounted for $69.62 \%$ compared to patients from the community accounted for $43.75 \%$; there was a difference in the rate of bacterial infection in the group of patients from the community and the group of patients transferred from other hospitals $(p<0.05)$. $99.4 \%$ of the patients had SOFA score greater than or equal to 2. Conclusion: The patients who had an infection at the time of admission to the ICU - Bach Mai Hospital were in serious condition. Most of the patients transferred from other places had multi-resistant Gramnegative bacteria. The group of patients with community-acquired infections also had more than $40 \%$ of multidrug-resistant Gram-negative bacteria.

Keywords: Gram-negative bacteria; multiresistant gram-negative bacteria; ICU

\section{I. ĐĂT VẤN ĐỀ}

Vi khuẩn gram âm là một trong những vấn đề sức khỏe cộng đồng quan trọng nhất trên thế giới do khả năng kháng thuốc kháng sinh cao. Một số nghiên cứu trên thế giới ghi nhận tỷ vi khuẩn gram âm đa kháng cao trên 53,8\% đối với họ Enterobacter spp và $100 \%$ đối với vi khuẩn $\mathrm{P}$. Aeruginosa và Acinetobacter spp [1]. Việc kê đơn, sử dụng kháng sinh quá mức của bác sĩ là một trong những nguyên nhân quan trọng thúc đẩy quá trình kháng kháng sinh. Bất chấp những nỗ lực trong việc quản lý sử dụng kháng sinh, báo cáo của Trung tâm Kiểm soát và Phòng ngừa dịch bệnh Hoa Kỳ gần đây đã ước tính khoảng 50\% thuốc kháng sinh được kê đơn không cần thiết ở Mỹ với chi phí hàng năm lên tới 1,1 tỷ đô la [2]. Những khuyến nghị về sử dụng kháng sinh ban đầu hợp lý, hiệu quả là rất cần thiết nhằm nâng cao hiệu quả điêu trị và giúp giảm nguy cơ kháng kháng sinh [3]. Với đặc thù của nguiôn bệnh nhân khi chuyển đến khoa Hồi sức tích cực bệnh viện Bạch Mai, mỗi bênh nhân mới vào viện có những đặc điểm nhiễm khuẩn khác nhau. Do đó, để xây dựng chiến lược sử dụng kháng sinh ban đầu hợp lý cần có những nghiên cứu đánh giá đầy đủ và hệ thống tình trạng nhiếm vi khuẩn đa kháng. Vì vậy chúng tôi tiến hành nghiên cứu "Tỷ lể nhiễm vi khuần gram âm đa kháng ở bệnh nhẩn mới vào khoa Hồi sức tích cực bệnh viện Bạch Mai năm 2020-2021" với mục tiêu mô tả tình hình nhiễm vi khuẩn gram âm đa kháng ở bệnh nhân mới vào khoa Hồi sức tích cực.

\section{II. ĐỐI TƯợNG VÀ PHƯƠNG PHÁP NGHIÊN CỨU 2.1. Đối tượng nghiên cứu * Tiêu chuân lứa chon}

Bệnh nhân vào điều trị tại khoa Hồi sức tích cực - Bệnh viện Bạch Mai, đã có nhiễm khuẩn ở thời điểm vào khoa.

- Bệnh nhân được sàng lọc nhiễm khuẩn khi được xác định có $\geq 2$ tiêu chuẩn sau: Sốt (> $38^{\circ} \mathrm{C}$ hoặc $<36^{\circ} \mathrm{C}$ ); nhịp tim $>90$ nhịp/phút; nhịp thở > 20 nhịp/phút hoặc $\mathrm{PaCO} 2<32$ $\mathrm{mmHg}$; bạch cầu máu $>12.000 / \mathrm{mL}$ hoặc < $4.000 / \mathrm{mL}$ hoặc $>10 \%$ tế bào non ở máu ngoại vi.

- Có kết quả nuôi cấy bệnh phẩm dương tính với vi khuẩn.

2.2. Thiết kế nghiên cứu: Nghiên cứu mô tả cắt ngang.

2.3. Cỡ mẫu và phương pháp mẫu: Chọn mẫu toàn bộ $(n=168)$ điều trị tại khoa Hồi sức tích cực đủ điều kiện tham gia nghiên cứu.

\subsection{Thời gian và địa điểm nghiên cứu}

- Địa điểm: Nghiên cứu được thực hiện tại khoa Hồi sức tích cực Bệnh viện Bạch Mai.

Thời gian: từ 01/8/2020 đến 31/8/2021.

2.5. Quy trình thu thập số liệu và xử lý số liệu. - Các xét nghiệm vi sinh được thực hiện tại khoa Vi sinh BVBM.

- Lấy bệnh phẩm nuôi cấy: theo quy trình của bệnh viện Bạch Mai.

- Bệnh phẩm được nuôi cấy, định danh VK bằng công nghệ phối khổ MALDI-TOF.

- Kháng sinh đồ được làm bằng phương pháp khoanh giấy khuếch tán. Mức độ nhạy của vi khuẩn với kháng sinh chia thành 3 mức: nhạy cảm ( $\mathrm{S}=$ Sensitive), trung gian ( $\mathrm{I}=$ Intermediate), và kháng $(\mathrm{R}=$ Resistance $)$. Đối với kháng sinh colistin, xác định độ nhạy cảm bằng $\mathrm{E}$ test.

* Định nghĩa: Vi khuẩn đa kháng - MDR (Multi Drug Resistant) là vi khuẩn không nhạy cảm với ít nhất 1 kháng sinh trong $\geq 3$ nhóm kháng sinh được thử; ví dụ các chủng vi khuẩn sinh beta-lactamase phổ rộng - ESBL (Extended Spectrum Beta-lactamase).

2.7. Đạo đức trong nghiên cứu. Quá trình nghiên cứu và thu thập thông tin được thông qua bởi Hội đồng đạo đức của Nhà trường và sự cho phép của Khoa Hồi sức tích cực Bệnh viện Bach Mai.

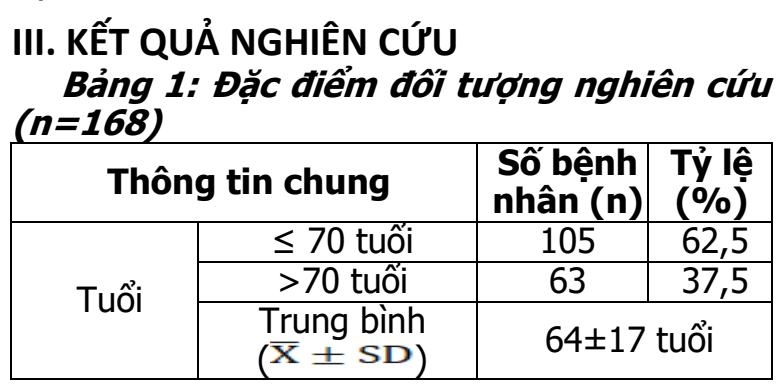




\begin{tabular}{|c|c|c|c|}
\hline \multirow{2}{*}{ Giới } & Nam & 122 & 72,62 \\
\cline { 2 - 4 } & Nữ & 46 & 27,38 \\
\hline \multirow{2}{*}{$\begin{array}{c}\text { Nơi chuyển } \\
\text { đến }\end{array}$} & $\begin{array}{c}\text { Khoa/Trung tâm } \\
\text { khác }\end{array}$ & 73 & 43,45 \\
\cline { 2 - 4 } & Bệnh viện khác & 79 & 47,02 \\
\cline { 2 - 4 } & Từ cộng đồng & 16 & 9,52 \\
\hline \multirow{2}{*}{$\begin{array}{c}\text { Can thieêp } \\
\text { thủ thuật }\end{array}$} & Thở máy & 146 & 86,9 \\
\cline { 2 - 4 } & Lọc máu & 52 & 30,95 \\
\cline { 2 - 4 } & Catheter TM trung & 68 & 40,48 \\
\hline
\end{tabular}

\begin{tabular}{|c|c|c|c|}
\hline & tâm & & \\
\cline { 2 - 4 } & Sonde tiếu & 68 & 40,48 \\
\hline
\end{tabular}

Nhận xét: $84 \%$ bệnh nhân được chuyển đến từ các bệnh viện khác hoặc khoa khác trong BVBM, phần lớn BN đã được làm thủ thuật xâm lấn.

Số bệnh nhân đã được dùng kháng sinh đường tĩnh mạch trước khi vào viện là 101/168 $(60,12 \%)$.

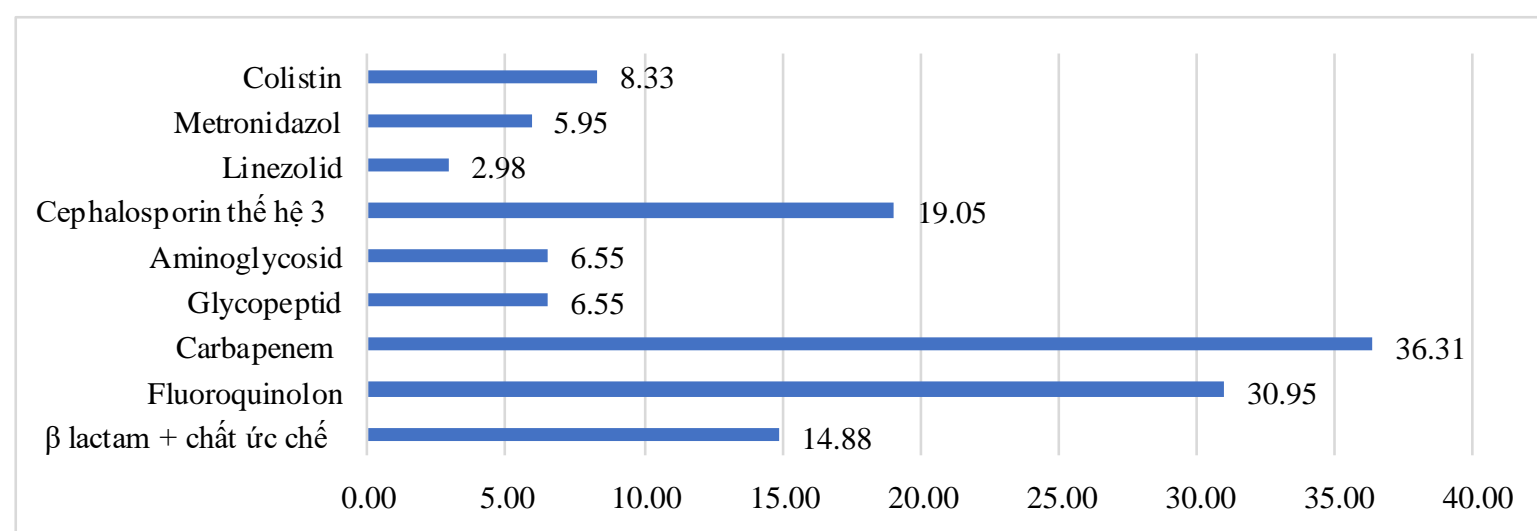

Biểu đồ 1. Tỷ lệ sử dụng kháng sinh trước nhiếm khuẩn trong vòng 30 ngày trước nhập viện

Nhận xét: Carbapenem và quinolon là 2 nhóm KS được sử dụng nhiêu nhất

Bảng 2. Đặc điểm mẫu nghiên cứu theo mức độ nặng thời điểm vào viện

\begin{tabular}{|c|c|c|c|}
\hline \multicolumn{2}{|c|}{ Đặc điếm mức độ nặng } & Tân số (n) & Tỷ lệ (\%) \\
\hline \multirow{3}{*}{ Điểm APACHE II } & $\leq 8$ điểm & 25 & 14,88 \\
\hline & $>8$ điếm & 143 & 85,12 \\
\hline & Trung bình $(\bar{x} \pm S D)$ & \multicolumn{2}{|c|}{$15,21 \pm 6,76$} \\
\hline \multirow{3}{*}{ Điểm SOFA } & $0-1$ điếm & 1 & 0,60 \\
\hline & $\geq 2$ điếm & 167 & 99,40 \\
\hline & Trung bình $(\mathrm{X} \pm \mathrm{SD})$ & \multicolumn{2}{|c|}{$8,04 \pm 4,63$} \\
\hline
\end{tabular}

Nhận xét: Tất cả BN vào khoa đều trong tình trạng nặng.

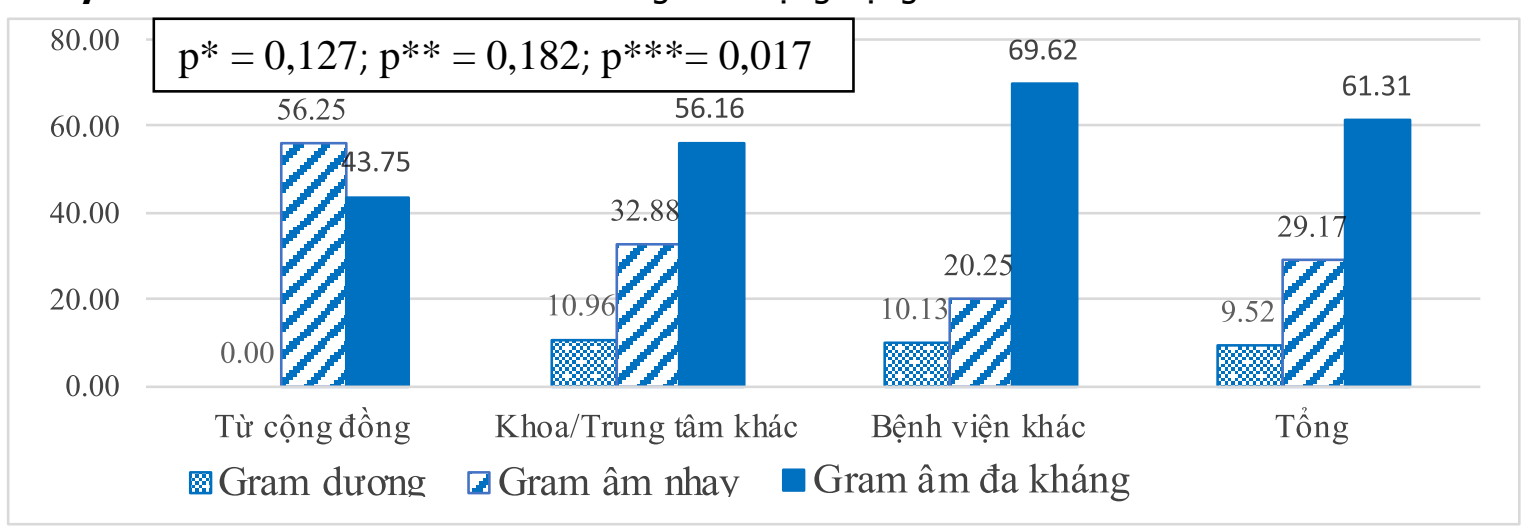

Biểu đồ 2. Phân bố tỷ lệ nhiễm vi khuẩn ở bệnh nhân mới vào khoa HSTC (n=168)

p*: So sánh sự khác biệt tỷ lệ vi khuẩn ở cộng đồng và khoa/trung tâm tâm khác

p**: So sánh sự khác biệt tỷ lệ vi khuẩn ở khoa/trung tâm tâm khác và bệnh viện khác

$\mathrm{p}^{* * *}$ : So sánh sự khác biệt tỷ lệ vi khuẩn ở cộng đồng và bệnh viện khác

Nhận xét: Tất cả các nhóm bệnh nhân đều có tỷ lệ gặp nhiễm khuẩn do VK Gram (-) đa kháng rất cao, kể cả nhóm $\mathrm{BN}$ vào viện từ cộng đồng. 


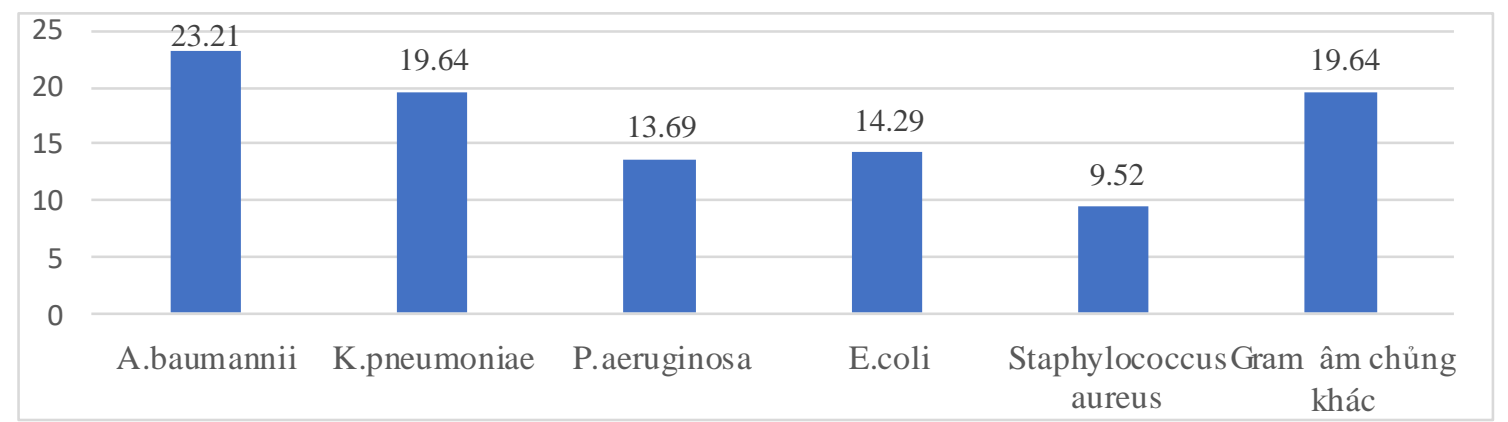

Biểu đồ 3. Tỉ lệ (\%) các chủng vỉ khuẩn ở bệnh nhân mới vào khoa Hồi sức tích cực - Bệnh viện Bạch Mai $(n=168)$

Nhận xét: Các VK thường gặp là A.baumannii, K.pneumoniae, P. aeruginosa, E. coli và tụ cầu.

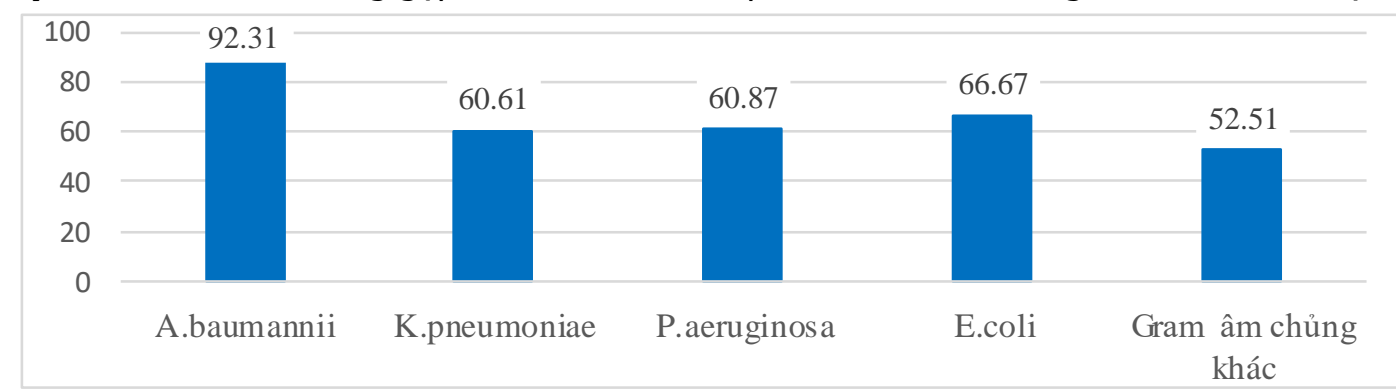

Biểu đồ 4. Phân bố tỉ lệ (\%) vi khuẩn gram âm đa kháng ở bệnh nhân mới vào khoa Hồi sức tích cức - Bênh viện Bach Mai (n=168)

Nhận xét: Vi khuẩn A.baumannii có tỷ lệ kháng thuốc cao nhất chiếm 92,31\%.

\section{BÀN LUẬN}

Đối tượng tham gia nghiên cứu có những đặc điểm chung tương đồng với các nghiên cứu đánh giá về tình trạng nhiễm khuẩn ở bệnh nhân tại các đơn vị Hồi sức cấp cứu tại Việt Nam và trên thế giới với độ tuổi trung bình cao trên 60 tuổi, chủ yếu là nam giới và có tỷ lệ thở máy cao trên 80\% [4], [5], [6]. Mức độ nặng tại thời điểm nghiên cứu trong nghiên cứu này theo thang điểm APACHE II trung bình là 15,21 thấp hơn so với nghiên cứu cũng tại Bạch Mai trên toàn bệnh viện năm 2018 với điểm trung bình là 17,8 [5]. Tuy nhiên, đánh giá mức độ nặng dựa theo thang điểm SOFA có điểm trung bình là 8,04 cao hơn so với nghiên cứu tại bệnh viện Bạch Mai năm 2018 và nghiên cứu của Vincent và cộng sự với điểm số trung bình lầ lượt là 6,0 và 7,2 [5], [6].

Nghiên cứu tiến hành đánh giá trên 168 bệnh nhân có kết quả cấy vi khuẩn dương tính ghi nhận tỷ lệ nhiếm gram âm chiếm $90,48 \%$; kết quả này cao hơn so với nghiên cứu của BediakoBowan năm 2020 trên 352 bệnh nhân có kết quả cấy vi khuẩn dương tính; Vincent năm 2021 trên 1150 đơn vị chăm sóc bệnh nhân; nghiên cứu của Agyepong với tỷ lệ lần lượt là $81 \% ; 67 \%$ và $80,6 \%$ [1], [4], [7]. Mặc dù có sự chênh lệch về tỷ lệ vi khuẩn Gram âm ở các nghiên cứu, tuy nhiên ở tất cả các nghiên cứu đều ghi nhận trong các vi khuẩn gây bệnh được phân lập, vi khuẩn gram âm chiếm chủ yếu trên $60 \%$. Điều này không có gì bất ngờ khi vi khuẩn gram âm đã được xác nhận là phổ biến hơn so với vì khuẩn gram dương trong các kết quả nuôi cây [4] và là một trong những vấn đề sức khỏe cộng đồng quan trọng nhất trên thế giới do khả nẳng kháng thuốc kháng sinh cao.

Bên cạnh đó, chúng tôi nhận thấy tỷ lệ nhiếm vi khuẩn gram âm đa kháng chiếm tỷ lệ cao ở những bệnh như từ bệnh viện khác chuyển tới $(69,62 \%)$; cao hơn so với từ khoa/trung tâm khác $(56,16 \%)$ và từ cộng đồng $(43,75 \%)$. Điều này có thể lý giải do những bệnh nhân từ ngoài cộng đồng chưa hoặc ít điêu trị bằng các loại kháng sinh dẫn đến tính trạng kháng kháng sinh thấp hơn. Ngoài ra, hầu hểt các vi khuẩn kháng thuốc đã được chỉ ra thường phổ biến ở bệnh viện hơn là trong cộng đồng [8]. Do đó, những bệnh nhân đang điêu trị tại khoa/trung tâm khác tại bệnh viện hoặc tại bệnh viện khác có thể đã nhiễm các vi khuẩn kháng thuốc trong bệnh viện; nên không có gì bất ngờ khi tỷ lệ kháng thuốc ở những nhóm đối tượng này cao hơn 
trong cộng đồng. Ngoài ra, những bệnh nhân được chuyển đến điều trị tại khoa HSTC thường là những bệnh nhân nặng, có thể đã nằm tại các khoa hồi sức tai các bệnh viên khác và mắc các nhiễm trùng bệnh viện; việc điều trị và sử dụng kháng sinh kéo dài hoặc sử dụng kháng sinh không cần thiết có thể là một trong những nguyên nhân dẫn đến tỷ lệ vi khuẩn đa kháng cao được phân lập.

Chúng tôi ghi nhận 5 vi khuẩn có tỷ lệ nhiễm cao nhất bao gồm: A.baumannii, K.pneumoniae, E.coli, P.aeruginosa và Staphylococcus aureus với tý lệ lần lượt là $23,21 \% ; 19,64 \% ; 13,69 \%$; $14,29 \%$ và $9,52 \%$. Kết quả này tương đồng với với các nghiên cứu về vi khuẩn gây bệnh cho thấy 5 vi khuẩn trên là nguyên nhân phổ biến gây nhiễm trùng ở bệnh nhân. Cụ thể, nghiên cứu tại bệnh viện Bạch Mai năm 2018 ghi nhận ba loại vi khuẩn A.baumannii; P.aeruginosa và K.pneumoniae có tỷ lệ nhiếm cao từ 20-40\% trong giai đoạn từ 2012-20016 [5]. Điêuu này là do phần lớn bệnh nhân vào khoa HSTC được đã điều trị trong các cơ sở y tế trước khi chuyển vào khoa, bao gồm: từ các khoa/trung tâm khác trong bệnh viện hoặc từ các bệnh viện khác chiếm $90,48 \%$; do đó, bệnh nhân có thể nhiễm các vi khuẩn bệnh viện từ các cơ sở, đơn vị chăm sóc này. Bên cạnh đó, các ghi nhận tại các bệnh viện cũng cho thấy 5 tác nhân trên là nguyên nhân phổ biến gây nhiễm khuẩn bệnh nhân tại các cơ sở y tế [4], [5], [7]. Từ các ngguyên nhân trên có thể lý giải cho tỷ lệ vi khuẩn được phân lập ở bệnh nhân mới và̀ khoa HSTĆ trong nghiên cứu của chúng tôi có sự tương đồng so với các nghiên cứu khác.

Bên cạnh đó, nghiên cứu dựa trên các kết quả kháng sinh đồ phân loại vi khuẩn ghi nhận vi khuẩn có tỷ lệ đa kháng cao nhất là vi khuẩn A.baumannii là $92,31 \%$; tiếp theo là E.coli chiếm $66,67 \%$; K.pneumoniae chiếm 60,61\%; P.aeruginosa chiếm $60,87 \%$; thấp nhất là các vi khuẩn gram âm khác chiếm $52,51 \%$. Kết quả này có sự khác biệt so với nghiên cứu của Bediako-Bowan và cộng sự ghi nhận tỷ lệ vi khuẩn gram âm đa kháng ở vi khuẩn A.baumannii là $52 \%$ thấp hơn so với nghiên cứu của chúng tôi, nhưng tỷ lệ đa kháng ở hai vi khuẩn E.coli và K.pneumoniae cao hơn so với nghiên cứu của chúng tôi với tỷ lệ lần lượt là là $86 \%$ và $86 \%$ [7]. Một nghiên cứu khác của Agyepong và cộng sự ghi nhận tỷ lệ đa kháng của vi khuẩn chiếm tỷ lệ cao hơn so với nghiên cứu của chúng tôi, cụ thể vi khuẩn Acinetobacter spp và $\mathrm{P}$. Aeruginosa có tỷ lệ vi khuẩn đa kháng là $100 \%$; K. pneumoniae và E.coli với tỷ lệ vi khuẩn đa kháng lần lượt là $94,7 \%$ và $89,9 \%$ [1]. Điều này có thể lý giải do nghiên cứu của chúng tôi tiến hành trên những bệnh nhân mới vào khoa Hồi sức tích cực trong 48 giờ sau khi được chuyển đến từ các bệnh viện khác, khoa/trung tâm khác trong bệnh viện hoặc từ cộng đồng; trong khi đó cả hai nghiên cứu trên đều tiến hành trên nhóm bệnh nhân đang nằm viện điều trị có thể trong một khoảng thời gian dài; do đó có thể dẫn đến tỷ lệ vi khuẩn đa kháng trong nghiên cứu của chúng tôi thấp hơn. Mặc dù có sự khác biệt về tỷ lệ đa kháng giữa các vi khuẩn, tưy nhiên cũng giống như các nghiên cứu khác chúng tôi nhấn mạnh tỷ lệ vi khuẩn đa kháng cao được tìm trong các bệnh phẩm. Bên cạnh đó, giống như các báo cáo gần đầy ghi nhận sự xuất hiện vi khuẩn A.baumannii với tỷ lệ nhiếm và kháng kháng sinh cao từ $50-100 \%$ [9]. Từ những kết quả về tỷ lệ nhiễm vi khuẩn gram âm và tỷ lệ vi khuẩn đa kháng cao, chúng tôi nhận thấy cần có những phác đồ điều trị kháng sinh hợp lý nhằm giảm tỷ lệ nhiễm vi khuẩn gram âm và vi khuẩn gram âm đa kháng.

\section{KẾT LUÂN}

Tỷ lệ nhiễm vi khuẩn gram âm đa kháng ở bệnh nhân mới vào khoa Hồi sức tích cực chiếm tỳ lệ cao trên $40 \%$; đặc biệt tỷ lệ vi khuẩn gram âm đa kháng cao hơn ở những bệnh nhân chuyển từ các khoa/trung tâm khác trong bệnh viện chiếm $56,16 \%$ và từ các bệnh viện khác chiếm $69,62 \%$ so với nhóm bệnh nhân từ cộng đồng chiếm $43,75 \%$. Tình hình nhiễm vi khuẩn gram âm nhất là vi khuẩn gram âm đa kháng ở bệnh nhân tại các đơn vị khác trong bệnh viện và̀ từ bệnh viện khác trước khi chuyển vào khoa HSTC là đặc biệt nghiêm trọng và chiếm tỷ lệ cao. Vi khuẩn A.baumannii có tỷ lệ mắc và tỷ lệ vi khuẩn đa kháng cao nhất chiếm tỷ lệ lần lượt là $23,21 \%$ và $92,31 \%$.

\section{TÀI LIÊUU THAM KHẢO}

1. Agyepong N., Govinden U., Owusu-Ofori A., et al. (2018). Multidrug-resistant gram-negative bacterial infections in a teaching hospital in Ghana. Antimicrob Resist Infect Control, 7, 37.

2. Center for Disease Control and Prevention (2013). Antibiotic Resistance Threats in the United States. Center for Disease Control and Prevention, Center for Disease Control and Prevention.

3. Centers for Disease Control and Prevention (2016). CDC: 1 in 3 antibiotic prescriptions unnecessary. Centers for Disease Control and Prevention, truy cập ngày 10/10/2021, tai trang web: <https://www.cdc.gov/media/releases/2016/p0503unnecessary-prescriptions.html> 
4. Vincent J.-L., Sakr Y., Singer $M_{. \prime}$ et al. (2020). Prevalence and Outcomes of Infection Among Patients in Intensive Care Units in 2017. JAMA, 323(15), 1478-1487.

5. Nguyễn Thi Tuyến (2018), Phân tích thực trang sứ dụng kháng sinh Carbapenem tại bệnh viện Bạch Mai, Luận văn thạc sĩ dược học, Trường đại hoc Dước Hà Nội, Hà Nối.

6. Vincent J.-L., Rello J., Marshall J., et al. (2009). International Study of the Prevalence and Outcomes of Infection in Intensive Care Units. JAMA, 302(21), 2323-2329.

7. Bediako-Bowan A.A.A., Kurtzhals J.A.L., Mølbak K., et al. (2020). High rates of multidrug resistant gram-negative organisms associated with surgical site infections in a teaching hospital in Ghana. BMC Infect Dis, 20, 890.

8. Centers for Disease Control and Prevention (2021). Antibiotic Resistant Germs in Hospitals: Information for Patients and their Families. Centers for Disease Control and Prevention, truy cập ngày 07/10/2021 tai trang web: <https://www.cdc.gov/ hai/patientsafety/ar-hospitals.html>.

9. Rizk S.S., Elwakil W.H., and Attia A.S. (2021). Antibiotic-Resistant Acinetobacter baumannii in Low-Income Countries (2000-2020): Twenty-One Years and Still below the Radar, Is It Not There or Can They Not Afford to Look for It?. Antibiotics, 10(7), 764 .

\title{
HIỆU QUẢ CỦA TIA PLASMA LANH TRONG HỖ TRỢ SAU ĐIỀU TRI NAO TÚI QUANH RĂNG TẠI TRUNG TÂM KỸ THUÂ̂T CAO RĂNG HÀM MĂT - TRƯỜNG ĐẠI HỌC Y HÀ NỘI
}

\author{
Đinh Thị Thái*, Vũ Mạnh Tuấn*, Trần Thị Mỹ Hạnh*, \\ Hoàng Kim Loan*, Nguyễn Phú Thắng*, Nguyễn Ngọc Anh*, \\ Tạ Thị Tươi*, Nguyễn Viết Đa Đô*
}

\section{TÓM TẮT}

Mục tiêu: Đánh giá hiệu quả của việc sử dụng tia plasma lanh trong hố trơ điêu tri phẫu thuât nao túi quanh răng sau theo dõi 3 tuần ở nhóm bệnh nhân có túi quanh răng từ 3 đến $5 \mathrm{~mm}$. Phương pháp nghiên cứu: 64 bệnh nhânvới 906 răng có túi quanh răng từ 3-5mm, được chia ngẫu nhiên thành hai nhóm can thiệp và nhóm chứng. Cả hai nhóm được phấu thuật nao túi quanh răng theo cùng một phương pháp, theo dỗi đánh giá tại các thời điểm sau 3 ngày và 3 tuândựa trên các chỉ số (DI, $\mathrm{PI}, \mathrm{CAL}, \mathrm{PD}$ và mức tốt/ khá), nhóm can thiệp được sử dụng tia plasma lạnh trong hỗ trợ điều trị phẫu thuật nạo túi quanh răng. Kết quả nghiên cứu: giá trị trung bình của chỉ số mảng bám răng (GI) sau 3 tuần giảm 1,8 ở nhóm can thiêp và 1,5 ở nhóm chứng. Trung bình số GI sau điều trị 3 tuần giảm 1,3 ở nhóm can thiêpp plasma và 1,1 ở nhóm chứng. Trung bình độ sâu túi quanh răng sau 3 tuần ở nhóm can thiệp giảm 1,8mm (từ $3.1702 \pm$ 0.3732 xuống $\left.1.3827^{\circ} \pm 0.3615\right)$, trong khi nhóm chứng chỉ giảm $1,2 \mathrm{~mm}$ (từ $3.1821 \pm 0.3852$ xuống còn $1.9102 \pm 0.4055)$. Tỷ lệ đạt kết quả tốt của nhóm can thiệp sau 3 ngày điêu trị là $96,9 \%$, và ở nhóm chứng là $37,5 \%$. Tỷ lê đat kết quả tốt của nhóm can thiệp sau 3 tuần điều trị chiếm 93,8\%, và ở nhóm chứng là 78,1\%. Kết luâan: Sử dụng tia plasma lạnh trong hỗ trợ điều trị phẫu thuật nạo túi quanh răng ở nhóm bệnh nhân có túi quanh răng từ 3 đến $5 \mathrm{~mm}$ có

*Viện Đào tạo Răng Hàm Mặt-Đại học Y Hà Nội

Chịu trách nhiệm chính: Đinh Thị Thái

Email: dinhthai@hmu.edu.vn

Ngày nhận bài: 3.8.2021

Ngày phản biên khoa hoc: 29.9.2021

Ngày duyệt bài: 6.10.2021 hiêuu quả cao.

Tư khóa: Nạo túi quanh răng, viêm quanh răng man tính, Plasma.

\section{SUMMARY}

THE EFFECTIVENESS OF USING COLD PLASMA AFTER CURETTAGE PERIODONTAL POCKETS AT HIGH TECHNICAL CENTER OF DENTISTRY - HA NOI MEDICAL UNIVERSITY

Objective: The purpose of this study was to evaluate the effectiveness of using cold plasma after curettage after 3 weeks of follow-up in the group of patients with 3 to $5 \mathrm{~mm}$ periodontal pockets. Methodology: The present study included 64 patients with 906 teeth which had 3-5 mm periodontal pockets divided into 2 groups: control and intervention group.Both groups had periodontal pocket curettage surgery according to the same method, evaluation after 3 days and 3 weeks based on indicators (DI, PI, $\mathrm{CAL}, \mathrm{PD}$ ) and levels of healing . Only the intervention group used cold plasma after periodontal pocket curettage surgery. Results: mean of plaque index (PI) in the 3rd week after treatment in the test and the control group decreased 1.8 and 1.5 times respectively. Another decrease was observed at mean of gingival index (GI), which decreased 1.3 times in test group and 1.1 times in control group.Mean of pocket depth (PD) also improved in both groups. Furthermore, the intervention group showed mean of PD decreasing more significantly $(1.8 \mathrm{~mm} ; 3.1702 \pm$ $0.3732,1.3827 \pm 0.3615$ before treatment and 3 weeks later, respectively) compared to the control one $(1,2 \mathrm{~mm} ; 3.1821 \pm 0.3852,1.9102 \pm 0.4055$ before treatment and 3 weeks later). The percentage of patients achieving good treatment outcomes accounted 